\title{
Study of SiC-nickel alloy bonding for high temperature applications
}

\author{
M.L. Hattali ${ }^{\text {a,* }}$, S. Valette ${ }^{\text {a }}$, F. Ropital ${ }^{\text {c }}$, G. Stremsdoerfer $^{\text {a }}$, N. Mesrati ${ }^{\text {b }}$, D. Tréheux ${ }^{\text {a }}$ \\ ${ }^{\text {a }}$ Laboratoire de Tribologie et Dynamique des Systèmes, UMR CNRS ECL ENISE ENSMSE 5513, École Centrale de Lyon, 69134 Ecully cedex, France \\ ${ }^{\mathrm{b}}$ Laboratoire de Sciences et Génie des Matériaux, École Nationale Polytechnique d'Alger, 10, avenue de Hassen Badi EL harrach Alger, Algeria \\ ${ }^{\mathrm{c}}$ IFP, BP 3-69360 Solaize, France
}

\begin{abstract}
We have studied the formation of metal/ceramic joints by solid state bonding technique for applications at temperatures $>600{ }^{\circ} \mathrm{C}$. The bonding is obtained between silicon carbide ( $\mathrm{SiC}$ ) and Ni-based super-alloy (HAYNES ${ }^{\circledR} 214^{\mathrm{TM}}$ ) via metallic foils (Ni, Ag). In some cases a thin coating on the ceramic or the alloy by the electroless JetMétal ${ }^{\mathrm{TM}}$ process has been used. Often used in brazing, nickel, when added to silicon carbide, usually give silicides. These reactions yield the "Pest Effect" ("pesting") that induces a catastrophic brittleness of this type of assembling. To minimize the reaction of these metals with silicon carbide, addition of elements limiting the "Pest Effect" on the one hand and, diffusion barriers on the other hand, have been performed. Indeed, the choice of the thin $\mathrm{Ni}_{0.93} \mathrm{~B}_{0.07}$ coating is based on the ability of boron of improving the mechanical properties of silicides, thus avoiding the "Pest Effect". However, we demonstrate that boron does not allow one to suppress the joint brittleness. Another new joining method employing a thin Ag coating or a Ag foil was tested. This process revealed the absence of chemical reaction at the $\mathrm{Ag} / \mathrm{SiC}$ interface, thus proving the beneficial role of silver, which acts as an effective diffusion barrier for nickel beyond a certain thickness. This method has led to fabrication of joints presenting high shear resistance ( $>40 \mathrm{MPa})$.
\end{abstract}

Keywords: Joining; Interface; Fracture; SiC; Ni-alloy

\section{Introduction}

Silicon carbide is a ceramic used up to a temperature of $1400-1600{ }^{\circ} \mathrm{C}$ whose applications concern not only electronic components (at high temperatures), but also mechanical equipments used in the chemical industry (mechanical joints, slide bearing ....). ${ }^{1}$ Thus, it must be often assembled with a metal placed in the zones that are less hot and less subjected to corrosion. Nowadays, the absence of satisfactory technological solutions for the realization of $\mathrm{SiC} /$ metal joints resisting high temperature ${ }^{2-4}$ is explained by the difficulty to find a solution to the chemical (primarily strong reactivity) and thermo-mechanical incompatibilities in particular the difference in the thermal expansion coefficient between ceramics and metals.

Many works have studied the wetting and the reactivity between $\mathrm{SiC}$ and metals such as $\mathrm{Al}^{3} \mathrm{Au}^{5,6} \mathrm{Cu},{ }^{6,7} \mathrm{Ni},{ }^{6-9} \mathrm{Co}^{8}$

\footnotetext{
* Corresponding author. Tel.: +33 472186517; fax: +33 478331140.

E-mail address:hattali.lamine@ JP DOFRP (M.L. Hattali).
}

Theoretically, all metals except $\mathrm{Al}$ and $\mathrm{Ag}$ must be avoided because they lead to the formation of brittle silicides. Moreover, aluminum melts at $660^{\circ} \mathrm{C}$ which can be insufficient for high temperature applications. ${ }^{10}$

According to their reactivity with $\mathrm{SiC}$ two groups of metals were defined ${ }^{14}$ :

(i) Metals reacting only with silicon and leading to the formation of silicides ( $\mathrm{Ni}, \mathrm{Co}, \mathrm{Fe}$, etc. ...). Silicide formation is accompanied by carbon precipitation in the form of graphitic layers which weaken the joints.

(ii) Metals able to react with both silicon and carbon ( $\mathrm{Zr}$, Ti, $\mathrm{Hf}, \mathrm{Mn}$, etc. ...). These metals can lead to a high reactivity with $\mathrm{SiC}$ that must be controlled in order to select the nature of the reaction products and the thickness within which the reaction occurs.

In the absence of chemical reactions, several interactions can explain the formation of non-reactive ceramic/metal bonding, ${ }^{11-13}$ namely: 
- evaporation-condensation,

- elasto-plastic adhesion and accommodation of the surfaces,

- creation of strong intra-molecular bonds.

The control of the reactivity is particularly significant for joints that must work at high temperatures. In fact, high temperature favors the growth of reaction layers and also causes an evolution of the non-controlled chemistry which is damaging for the mechanical resistance of the joint. Moreover, during cooling, the mismatch between the thermal expansion coefficient of the materials of joint can cause fractures. ${ }^{12}$

\section{Experimental procedure}

Silicon carbide (ESK Ceramics type EKasic ${ }^{\circledR} \mathrm{F}$ ) was bonded to a $\mathrm{Ni}$ super-alloy (HAYNES ${ }^{\circledR} 214^{\mathrm{TM}}$ ) with $\mathrm{Ni}$, and Ag metallic foils. Metallic interlayers can reduce residual stresses in the bi-material and the choice of the metals is based on the melting point that must be high. The alloy HAYNES ${ }^{\circledR} 214^{\mathrm{TM}}$ is chosen in this study because it is used in technological applications at high temperatures and in severe chemical atmosphere such as that encountered in industrial heating market (petrochemical, etc. ...). All base material blocks were cut into small pieces $(15 \mathrm{~mm} \times 5 \mathrm{~mm} \times 5 \mathrm{~mm})$ for bonding and for shear test. Both $\mathrm{Ni}$ and $\mathrm{Ag}$ foils were prepared by cold rolling down to a thickness of $200 \mu \mathrm{m}$ and had the same dimensions of material blocks.

In some experiments, $\mathrm{Ni}_{0.93} \mathrm{~B}_{0.07}$ or pure $\mathrm{Ag}$ thin coatings were deposited on ceramics or alloys by the electroless JetMétal ${ }^{\mathrm{TM}}$ process. ${ }^{15,16}$ The choice of $\mathrm{Ni}_{0.93} \mathrm{~B}_{0.07}$ is based on the ability of boron to improve the mechanical properties of silicides and thus to avoid the "Pest effect". ${ }^{17-19}$ The silver coating is used as diffusion barrier.

The compositions of the metals and ceramic selected to produce the studied $\mathrm{M} / \mathrm{C}$ joints were:

1. Nickel foil - (99.5\% purity; $200 \mu \mathrm{m}$ thick);

2. $\mathrm{NiB}$ coating $-(93 \% \mathrm{Ni}, 7 \% \mathrm{~B} ; 2 \mu \mathrm{m}$ thick $)$;

3. Silver coating $-(99.9 \%$ purity; $2 \mu \mathrm{m}$ thick);

4. Silver foil - (99.9\% purity; $200 \mu \mathrm{m}$ thick);

5. HAYNES $^{\circledR} 214^{\mathrm{TM}}-\mathrm{Ni}$ super-alloy $(75 \% \mathrm{Ni}, 16 \% \mathrm{Cr}, 4.5 \%$

$\mathrm{Al}, 3 \% \mathrm{Fe}$ );

6. $\mathrm{SiC}-\mathrm{EKasic}^{\circledR}-\mathrm{F}(>99.2 \%$ purity).

Prior to the solid state bonding, the surface of ceramics was polished, using diamond paste $(14-1 \mu \mathrm{m})$, to reach a mirror finish. The surfaces of the metallic interlayers and alloy were lightly polished with silicon carbide abrasive paper in order to remove any oxidation layers. All surfaces were

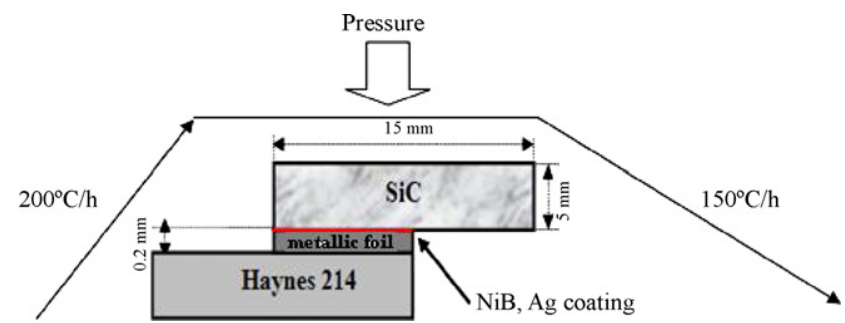

Fig. 1. Schematic view of the sample and of the temperature cycle used for the solid state bonding.

ultrasonically cleaned by acetone and ethanol for $10 \mathrm{~min}$. Finally, ceramic-metal-alloy 'sandwiches' were hot-pressed at a temperature lower than the melting point of the metal and alloy at a pressure of $16 \mathrm{MPa}$. The heating rate was $150^{\circ} \mathrm{C} / \mathrm{h}$ and the cooling rate was $200^{\circ} \mathrm{C} / \mathrm{h}$. Bonding was carried out in a primary dynamic vacuum $\left(10^{-3} \mathrm{~Pa}\right)$ during the complete temperature cycle (Fig. 1). The different bonding conditions are presented in Table 1 . They were selected taking into account previous studies on alumina/Ni/alumina, ${ }^{13}$ alumina/Cu/alumina ${ }^{20}$ and alumina/Ag/alumina ${ }^{21}$ systems.

The geometry of the samples was chosen taking into account the possibility of realizing mechanical (shear test) and microstructural analysis (Fig. 1). After bonding, the interfacial regions and the fracture surfaces of $\mathrm{SiC} /$ metal joints were observed and analyzed by SEM/EDX and X-ray diffraction (XRD). Shear strength measurements were performed using an Instron testing machine. The testing was carried out at the constant crosshead speed of $0.1 \mathrm{~mm} / \mathrm{min}$, and the strength was calculated by the load at the fracture divided by the nominal area of the joint. Even if a pure shear stress field does not necessarily occur in this testing technique, it is, nonetheless, a suitable means for comparative evaluations.

\section{Results and discussion}

During this study, three different experimental routes were followed:

Route-1: Use of $\mathrm{Ni}_{0.93} \mathrm{~B}_{0.07}$ pre-metallization ( $2 \mu \mathrm{m}$ thickness) to prevent "Pest Effect" and verification of the reactivity of $\mathrm{SiC}$ with Ni foil and Ni-based super-alloy.

Route-2: Use of pure silver as thin diffusion barrier $(2 \mu \mathrm{m}$ thickness).

Route-3: Use of pure silver foils as thick diffusion barrier (200 $\mu \mathrm{m}$ thickness).

Table 1

Experimental conditions for the joining of silicon carbide with different metallic foils ( $\mathrm{Ni}, \mathrm{Ag})$ and coatings $\left(\mathrm{Ni}_{0.93} \mathrm{~B}_{0.07} \mathrm{and} \mathrm{Ag}\right)$

\begin{tabular}{|c|c|c|c|c|c|c|}
\hline & Temperature $\left({ }^{\circ} \mathrm{C}\right)$ & Pressure (MPa) & Time (h) & $e_{\text {foil }}(\mu \mathrm{m})$ & $e_{\text {coating }}(\mu \mathrm{m})$ & Vacuum $(\mathrm{Pa})$ \\
\hline $\mathrm{SiC} / \mathrm{Ni}_{0.93} \mathrm{~B}_{0.07} / \mathrm{Ni}-\mathrm{HAYNES}{ }^{\circledR} 214^{\mathrm{TM}}$ & 1100 & 16 & 1 & 200 & 2 & $10^{-3}$ \\
\hline $\mathrm{SiC} / \mathrm{Ag} / \mathrm{HAYNES}^{\circledR} 214^{\mathrm{TM}}$ & 910 & 6 & 1 & 200 & 0 & $10^{-3}$ \\
\hline $\mathrm{SiC} / \mathrm{Ag} / \mathrm{HAYNES}{ }^{\circledR} 214^{\mathrm{TM}}$ & 910 & 6 & 1 & - & 2 & $10^{-3}$ \\
\hline
\end{tabular}




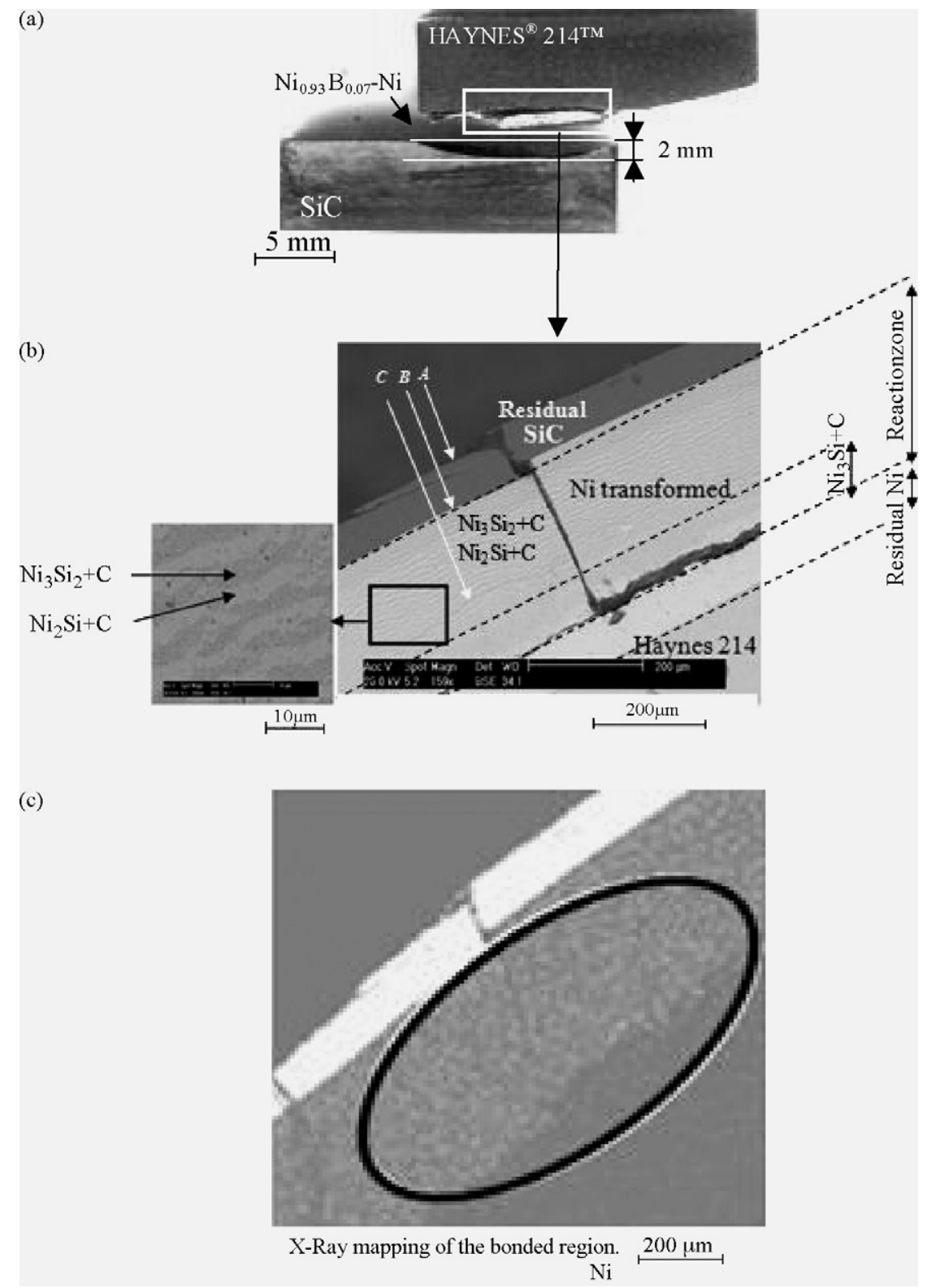

Fig. 2. Cross-section of $\mathrm{SiC} / \mathrm{Ni}_{0.93} \mathrm{~B}_{0.07} / \mathrm{Ni} / \mathrm{HAYNES}^{\circledR} 214^{\mathrm{TM}}$ joint $\left(1150^{\circ} \mathrm{C}\right.$ for $1 \mathrm{~h} ; 16 \mathrm{MPa}$ pressure). (a) Optical macrograph of the reaction zone and (b) backscattered electron image and EDX analysis, of interfacial zone. (A-C) Are relative to the XRD analysis (see Fig. 3) and (c) X-ray mapping of the bonded region.

\section{1. $\mathrm{SiC} / \mathrm{Ni}_{0.93} \mathrm{~B}_{0.07} / \mathrm{Ni} / \mathrm{HAYNES^{ \circledR }} 214^{\mathrm{TM}}$}

At temperatures $>700^{\circ} \mathrm{C}$, nickel in the presence of $\mathrm{SiC}$ can give several reactions stemming from the $\mathrm{Ni}-\mathrm{Si}$ equilibrium phase Diagram ${ }^{10}$ and depending on the silicon concentration and temperature. Particularly, nickel silicides can be formed. ${ }^{10,11,14,22,23}$

Scanning Electronic Microscopy (SEM) examinations of the $\mathrm{SiC} / \mathrm{Ni}_{0.93} \mathrm{~B}_{0.07} / \mathrm{Ni} / \mathrm{HAYNES}^{\circledR} 214^{\mathrm{TM}}$ joints shows that a reaction between nickel and silicon carbide occurs and, despite the presence of boron, the joint is weakened with cracking silicides (Fig. 2b) and break of $\mathrm{SiC}$ (Fig. 2a). The depth of the reaction zone varies from 100 to $200 \mu \mathrm{m}$. Johnson and Rowcliffe ${ }^{24}$ showed that the difference in the thermal expansion coefficient between the ceramics and met- als can cause failure because of residual stresses. In our case, it was difficult to distinguish the problem of residual stresses from the problem of chemical reactivity at high temperatures.

Quantitative analysis by EDX has revealed the formation, in the zone occupied initially by the $\mathrm{Ni}$ interlayer, of three phases rich in $\mathrm{Si}$, containing respectively $38.6,31.2$ and 26.4 at.\% Si. The X-ray map for $\mathrm{Ni}, \mathrm{Si}$ and $\mathrm{C}$, illustrates that the $\mathrm{C}$ is distributed in the depth of the reaction zone, and that a graphite-rich phase has been formed (Fig. 2c).

From the X-ray diffraction analysis after fracture of the assembly, we can recognize the presence of Ni-silicides such as $\gamma \mathrm{Ni}_{3} \mathrm{Si}_{2}$ (hexagonal), $\delta \mathrm{Ni}_{2} \mathrm{Si}$ (hexagonal) and graphite (Fig. 3). The third phase $\beta_{N_{3}} \mathrm{Si}$ (cubic) has been detected after total removal of the residual $\mathrm{SiC}$ layer after several polishes. 


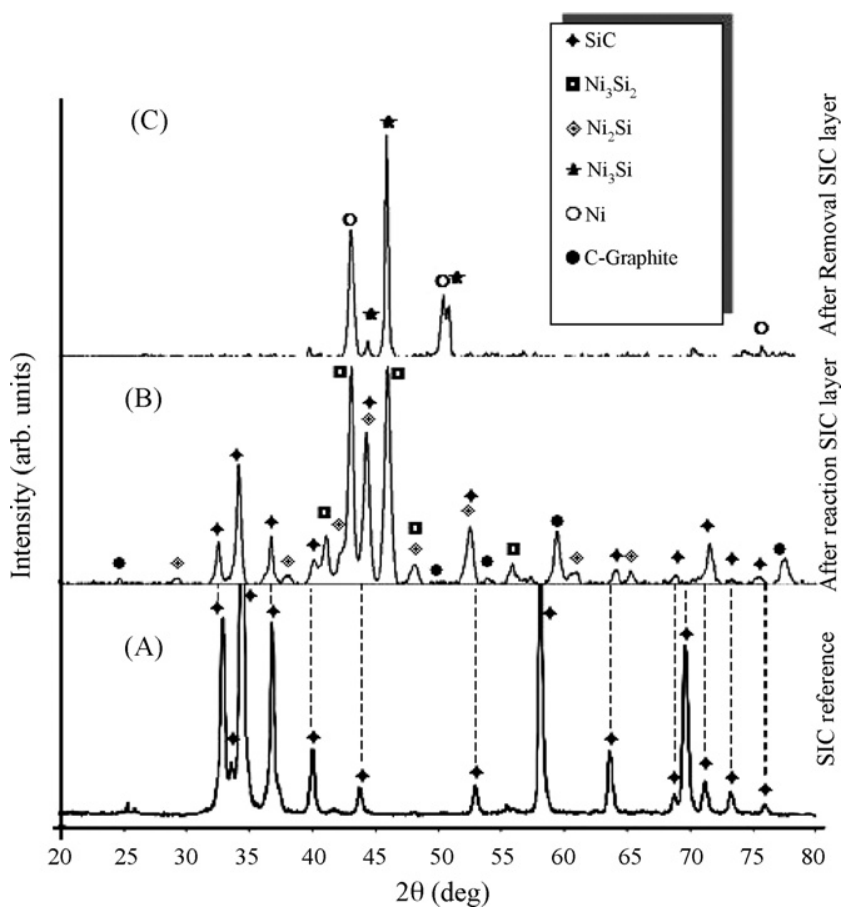

Fig. 3. X-ray diffraction patterns $\left(\lambda_{\mathrm{k} \alpha} \mathrm{Cu}\right)$ of: (A) $\mathrm{SiC}$; (B) fractured surface of the $\mathrm{SiC}$ joint (reaction zone); (C) reaction zone after removal of the residual $\mathrm{SiC}$ ((A-C) positions: see Fig. 2).

$\gamma \mathrm{Ni}_{3} \mathrm{Si}_{2}$ and $\delta \mathrm{Ni}_{2} \mathrm{Si}$ form a duplex structure consisting of alternating layers to a depth of $170 \mu \mathrm{m}$. According to the $\mathrm{Ni}-\mathrm{Si}$ equilibrium phase Diagram ${ }^{10}$ (Fig. 4) and our observations (Fig. 2b) we can suppose that the phases $\theta$ and $\beta-\mathrm{Ni}_{3} \mathrm{Si}$ have been formed at $1100^{\circ} \mathrm{C}$, then, after cooling, at $806^{\circ} \mathrm{C}, \theta$ is decomposed by eutectoid reaction in $\gamma \mathrm{Ni}_{3} \mathrm{Si}_{2}+\delta \mathrm{Ni}_{2} \mathrm{Si}$. At the same time, graphite is released and precipitates. ${ }^{10,25} \mathrm{\beta Ni}_{3} \mathrm{Si}$ has a thickness of $70 \mu \mathrm{m}$ and is highly brittle. The brittleness is accompanied by a crack along the residual $\mathrm{Ni} / \mathrm{Ni}_{3} \mathrm{Si}$ interface (Fig. 2b) which can be attributed to the differences in the thermal expansion coefficients. Similar results were obtained by Schiepers et al. ${ }^{11}$ after heat treatment of the $\mathrm{SiC} / \mathrm{Ni}$ system at $850^{\circ} \mathrm{C}$ for $44 \mathrm{~h}$.

\section{2. $S i C / A g / H A Y N E S^{\circledR} 214^{\mathrm{TM}}$}

\subsubsection{Use of a Ag thin coating}

Theoretically, silver is a metal that cannot react with $\mathrm{Si}$ and cannot form brittle silicides. ${ }^{10}$ Consequently, $\mathrm{SiC}$ was joined to Ni-based alloy $\left(\right.$ HAYNES $^{\circledR} 214^{\mathrm{TM}}$ ) using a Ag coating $(\approx 2 \mu \mathrm{m})$ deposited by the electroless JetMétal ${ }^{\mathrm{TM}}$ process. The analysis of the $\mathrm{SiC} / \mathrm{Ag}^{\circledR} / \mathrm{HAYNES}^{\circledR} 214^{\mathrm{TM}}$ joint shows a partial chemical reaction of $\mathrm{Ni}$ (element of the alloy) with $\mathrm{SiC}$, which causes the fracture of the joint at the alloy/SiC interface (Fig. 5a).

EDX analysis on the fracture surface of $\mathrm{SiC}$ side has shown traces of nickel on SiC (Fig. 5b). Two reasons may explain the presence of $\mathrm{Ni}$ on the $\mathrm{SiC}$. First, the observation of the joint by SEM after fracture shows that the Ag coating is discontinuous after bonding (Fig. 6b). Thus, nickel can diffuse through these discontinuities and then react with $\mathrm{SiC}$.

Therefore it seems necessary to increase the thickness of the Ag coating. Second, Heurtel and co-workers ${ }^{26}$ explained that

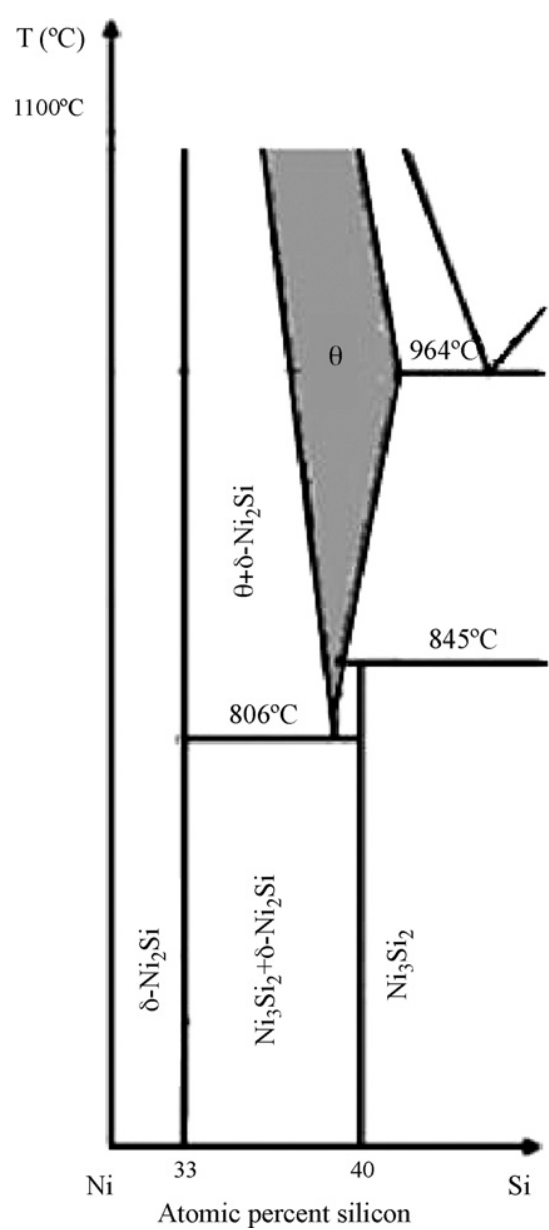

Fig. 4. Ni-Si equilibrium phase Diagram ${ }^{10}$.

the elements having a low mutual chemical solubility, such as nickel and silver ${ }^{10}\left(D_{\mathrm{v}(\mathrm{Ni} \rightarrow \mathrm{Ag})}\right.$ at $\left.910^{\circ} \mathrm{C}=5.10^{-13} \mathrm{~m}^{2} / \mathrm{s}\right),{ }^{27}$ diffuse at a faster rate than those having a significant solubility. The diffusion of Ni through the Ag coating may result in the formation of a brittle layer of nickel silicide between $\mathrm{SiC}$ and $\mathrm{Ag}$ that can lead to a fracture at this interface. It appears, after calculation and using the diffusion law, $e=\sqrt{ } D t$ (e, depth of diffusion, $D_{\mathrm{v}}$, diffusion coefficient and $t$, diffusion time) that the diffusion depth of nickel in silver is about $43 \mu \mathrm{m}$ for $1 \mathrm{~h}$ at $910^{\circ} \mathrm{C}$ (conditions used for solid state bonding).

However, it should be noted that even with these thin thicknesses $(\approx 2 \mu \mathrm{m})$, the $\mathrm{Ag}$ coating has greatly restricted the reactivity (see Figs. 2 and 6). Therefore a thick silver foil or deposit $(>50 \mu \mathrm{m})$ could be an interesting technological solution.

\subsubsection{Use of a Ag thick foil}

Based on the aforementioned result, $\mathrm{SiC}$ was joined to $\mathrm{Ni}$ based alloy $\left(\mathrm{HAYNES}^{\circledR} 214^{\mathrm{TM}}\right.$ ) using a Ag foil $(\approx 200 \mu \mathrm{m})$. The analysis of the cross sections of SiC/Ag/HAYNES ${ }^{\circledR} 214^{\mathrm{TM}}$ with Scanning Electronic Microscopy (SEM) shows that the additional metal does not give the formation of new phases at the $\mathrm{Ag} / \mathrm{SiC}$ interface at the scale used for our observation. Indeed, Fig. $7 \mathrm{~b}$ and $\mathrm{c}$ show a good adaptation of $\mathrm{Ag}$ to $\mathrm{SiC}$. However, the presence of oxides and porosities at the Ag/HAYNES ${ }^{\circledR} 214^{\mathrm{TM}}$ 
(a)

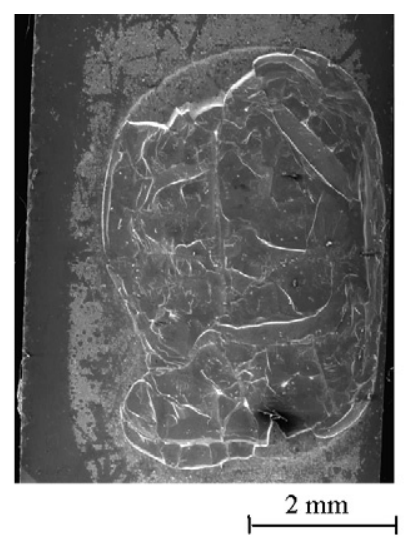

(b)
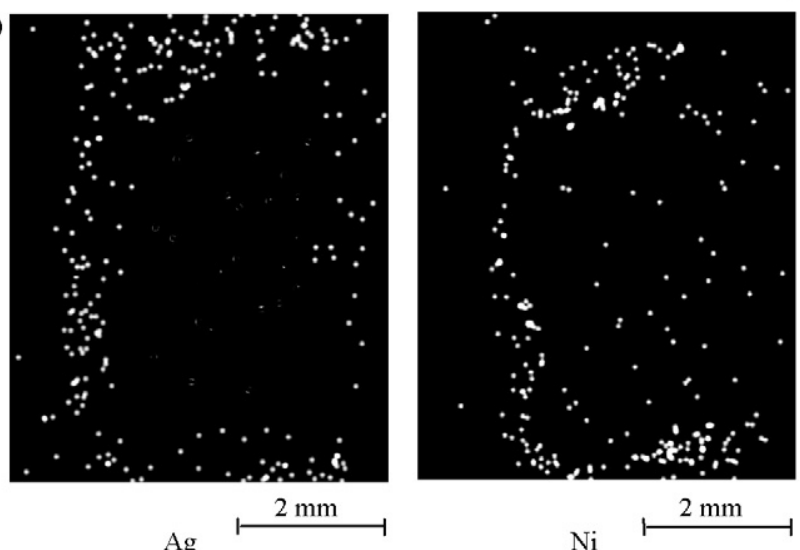

$\mathrm{Ni}$

$2 \mathrm{~mm}$

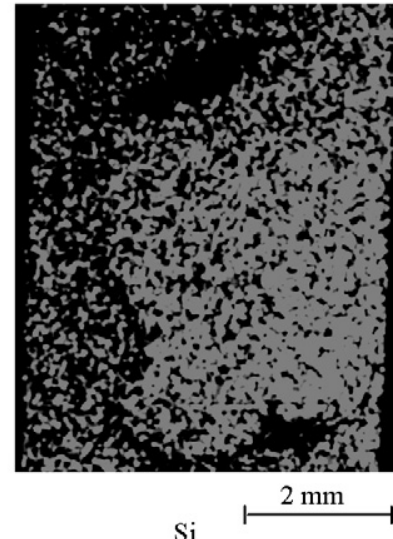

Fig. 5. SEM micrographs of SiC surface, after fracture of the SiC/Ag ${ }^{\circledR} / \mathrm{HAYNES}^{\circledR} 214^{\mathrm{TM}}$ bond, realized with a thin $\mathrm{Ag}$ coating $(\approx 2 \mu \mathrm{m}$ thickness). (a) $\mathrm{SEM}$ and (b) X-ray mapping.

interface is observed. It can be concluded that a vacuum of $10^{-3} \mathrm{~Pa}$ is insufficient to avoid the oxidation of the alloy.

The previously diffusion calculation applied to the Ag foil $(\approx 200 \mu \mathrm{m})$ gives the estimate of the time of diffusion of $\mathrm{Ni}$ through the silver foil, for various temperature of use of the joint (Table 2). From this calculation it can be concluded that this solution is very interesting for potential industrial applications in the $600-800^{\circ} \mathrm{C}$ temperature range.

The mechanical resistance of the joints was determined by fracture shear test. These tests were aimed at evaluating the

(a)

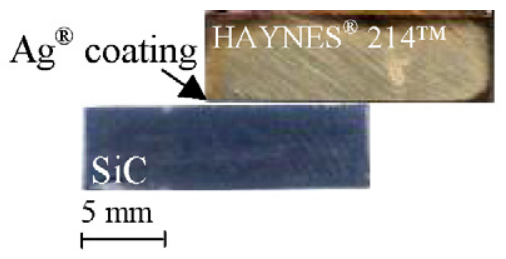

(b)
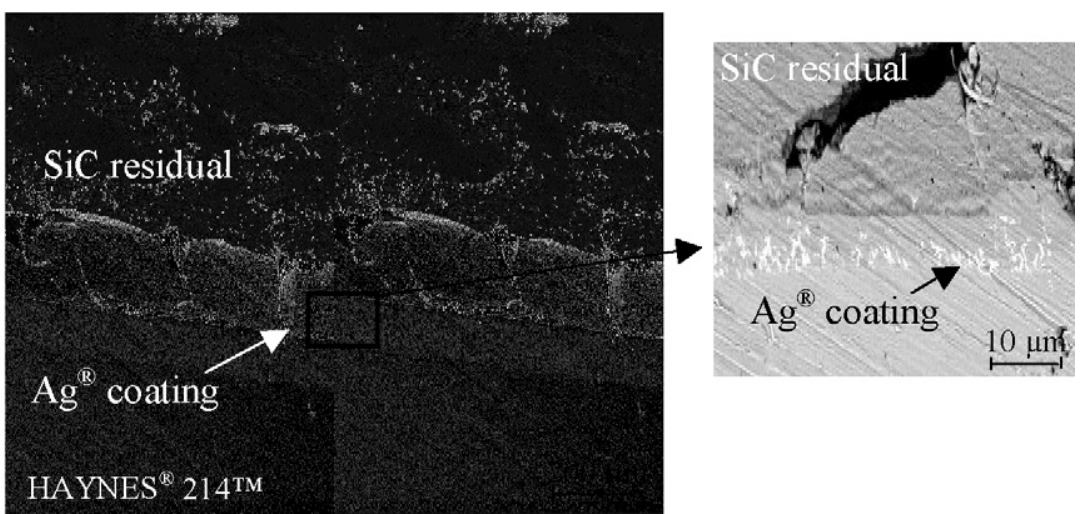

Fig. 6. Cross-section of SiC/Ag ${ }^{\circledR} / \mathrm{HAYNES}^{\circledR} 214^{\mathrm{TM}}$ joint. (a) Optical macrograph of the reaction zone, and (b) SEM microphotographs of SiC/HAYNES ${ }^{\circledR} 214^{\mathrm{TM}}$ interface showing weak reactivity of $\mathrm{Ni}$ with $\mathrm{SiC}$ and discontinuity of $\mathrm{Ag}$ thin coating after bonding. 
(a)
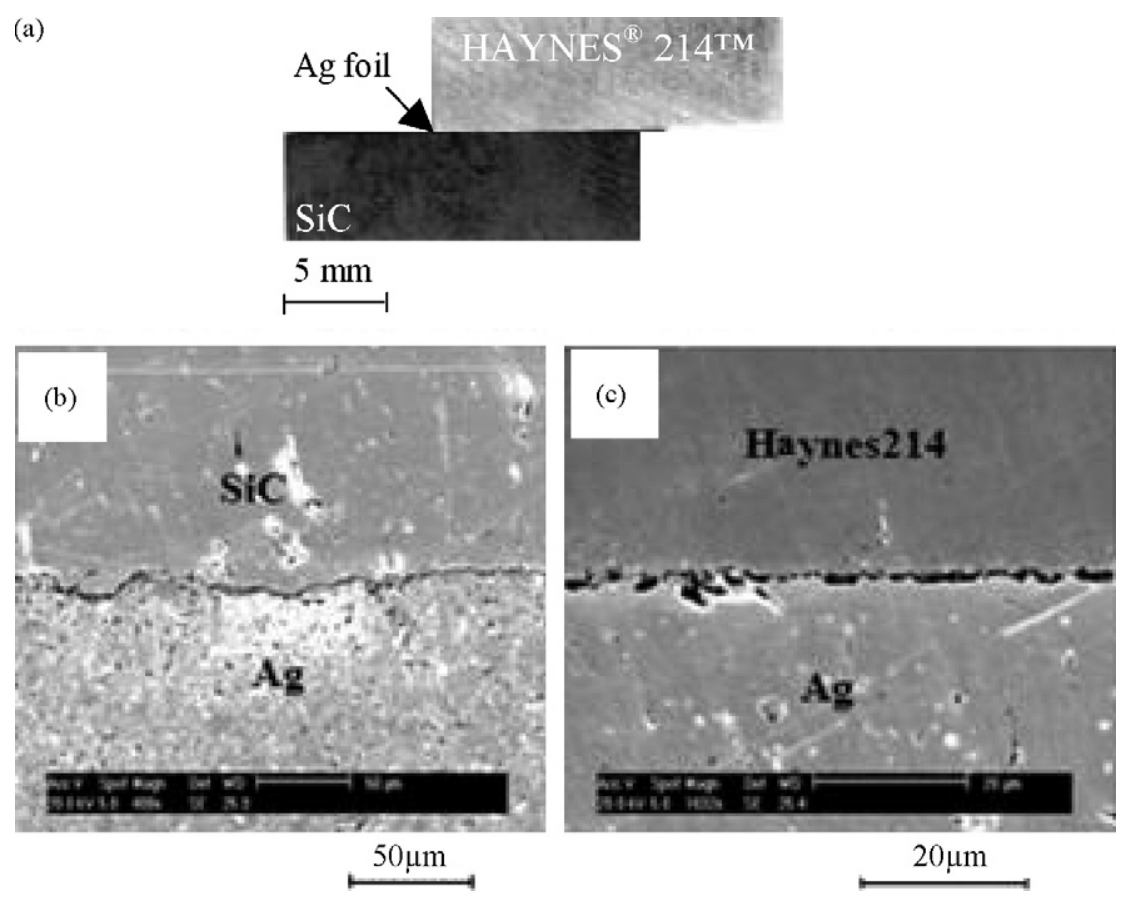

Fig. 7. Cross-section of SiC/Ag/HAYNES ${ }^{\circledR} 214^{\mathrm{TM}}$ joint. (a) Optical macrograph of the no reactive zone. Cross-sectional Scanning Electron Micrograph of the $\mathrm{SiC} / \mathrm{Ag} / \mathrm{HAYNES}{ }^{\circledR} 214^{\mathrm{TM}}$ joint, (b) SiC/Ag interface, and (c) HAYNES ${ }^{\circledR} 214^{\mathrm{TM}} / \mathrm{Ag}$ interface.

bonding of $\mathrm{SiC} / \mathrm{Ag}$ joints. Three samples were tested. The results obtained for $\mathrm{SiC} / \mathrm{Ag} / \mathrm{HAYNES}{ }^{\circledR} 214^{\mathrm{TM}}$ joints using $\mathrm{Ag}$ foil are about $25 \pm 6 \mathrm{MPa}$ and rupture is of adhesive type at the Ag/HAYNES ${ }^{\circledR} 214^{\mathrm{TM}}$ interface. These results may be attributed to the oxidation of the alloy and to the low solubility of silver in nickel and chromium which are the main elements of the alloy. To improve the quality of the interface Ag/HAYNES ${ }^{\circledR}$ $214^{\mathrm{TM}}$, another bonding was realized with the same conditions as indicated above, but with a thin $\mathrm{Ni}_{0.93} \mathrm{~B}_{0.07}$ coating $(\approx 2 \mu \mathrm{m})$ on the Ni-based super-alloy. The fracture shear stress was thus improved up to $45 \pm 9 \mathrm{MPa}$ with an adhesive fracture along the Ag/HAYNES ${ }^{\circledR}$ interface and without interfacial reaction. It seems that the metallization by $\mathrm{Ni}_{0.93} \mathrm{~B}_{0.07}$ improves the mechanical behavior of the bond through the $\mathrm{Ni}-\mathrm{Ag}$ interaction at the interface $\mathrm{Ag} / \mathrm{HAYNES}^{\circledR} 214^{\mathrm{TM}}$ and avoids the oxidation of the alloy.

To conclude, Figs. 2, 6 and 7 show cross-section of different systems studied. It was confirmed that only by using a thick Ag foil $(\approx 200 \mu \mathrm{m})$, it was possible of avoiding the chemical reaction of $\mathrm{SiC}$ with $\mathrm{Ni}$ alloys.

Table 2

Theoretical life times calculated from the Ni diffusion into Ag in the case of SiC/Ag/HAYNES ${ }^{\circledR} 214^{\mathrm{TM}}$ joints, using a Ag foil (200 $\mu \mathrm{m}$ thickness), for different temperatures

\begin{tabular}{lclr}
\hline & $\begin{array}{l}\text { Diffusion } \\
\text { coefficient }^{26}\left(\mathrm{~m}^{2} / \mathrm{s}\right)\end{array}$ & $\begin{array}{l}\text { Temperature } \\
\left({ }^{\circ} \mathrm{C}\right)\end{array}$ & $\begin{array}{l}\text { Life time } \\
(\mathrm{h})\end{array}$ \\
\hline & $5 \times 10^{-17}$ & 600 & $>200,000$ \\
SiC/Ag/HAYNES $^{\circledR} 214^{\mathrm{TM}}$ & $10^{-15}$ & 700 & $>10,000$ \\
& $10^{-14}$ & 800 & $>1000$ \\
& $5 \times 10^{-13}$ & 900 & $\approx 22$ \\
\hline
\end{tabular}

\section{Conclusions}

In spite of its technological interest for thermo-mechanical applications, silicon carbide creates some problems for the elaboration of metal/SiC bonds, because of its strong reactivity with various metals which leads to the formation of brittle silicides. Thus, to resolve this problem different SiC/HAYNES ${ }^{\circledR} 214^{\mathrm{TM}}$ joints were realized, using: a $\mathrm{Ni}_{0.93} \mathrm{~B}_{0.07}$ coating, a Ag coating, and a Ag foil. In the first case, we demonstrate that the addition of boron through the medium of the $\mathrm{Ni}_{0.93} \mathrm{~B}_{0.07}$ coating is not sufficient to avoid brittleness of silicides submitted at high residual stress during realization. In the second case, the use of a $\mathrm{Ag}$ coating $(\approx 2 \mu \mathrm{m})$ significantly avoids the reaction of $\mathrm{SiC}$ with Ni. Thus, the non-uniformity of the Ag coating after bonding and the possibility of $\mathrm{Ni}$ to diffuse through the $\mathrm{Ag}$ coating led us to conclude that only a sufficient thickness $(>50 \mu \mathrm{m})$ can prevent a catastrophic reaction at $900^{\circ} \mathrm{C}$. Finally, a new approach to joining $\mathrm{SiC}$ for high temperature applications $\left(600^{\circ} \mathrm{C}<T<800^{\circ} \mathrm{C}\right)$ using a thick $\mathrm{Ag}$ foil $(\approx 200 \mu \mathrm{m})$ has been explored; the capability of forming strong $\mathrm{SiC} / \mathrm{Ag} / \mathrm{HAYNES}^{\circledR} 214^{\mathrm{TM}}$ joint to avoid reaction between $\mathrm{SiC}$ and $\mathrm{Ni}$ has been demonstrated. The use of a silver foil $(\approx 200 \mu \mathrm{m})$ between $\mathrm{SiC}$ and Ni-based super-alloy (HAYNES $^{\circledR} 214^{\mathrm{TM}}$ ) improves the mechanical shear resistance, up to $45 \pm 9 \mathrm{MPa}$, which can permit industrial applications at $700{ }^{\circ} \mathrm{C}$ for more than $10000 \mathrm{~h}$.

\section{References}

1. Iwamoto, N., Umesaki, N., Kamai, M. and Ohnishi, K., Metal-ceramic interfaces. Acta-Scripta Metallurg, 1989, 4, 176-181.

2. Ferro, A. C. and Derby, B., Wetting behaviour in the Al-Si/SiC system: interface reactions and solubility effects. Acta Metal Mater., 1995, 43, 3061. 
3. Projet Brite-Euram AMBRA - Production of high temperature resistance joints between engineering ceramics and metals by active metals brazing Final Technical Report, Brite-Euram Program, Contract BRE2-CT92-0350 October 1997.

4. Locatelli, M. R., Dalgleich, B. J., Nakashima, K., Tomsia, A. P. and Glaeser, A. M., New approaches to joining ceramics for high temperature application. Ceram. Int., 1997, 23, 313-322.

5. Drevet, B., Kalogerolpolou, S. and Eustathopoulos, N., Wettability and interfacial bonding in $\mathrm{Au}-\mathrm{Si} / \mathrm{SiC}$ system. Acta Metal Mater, 1993, 41, 3119.

6. Rado, C., Drevet, B. and Eustathopoulos, N., The role of compound formation in reactive wetting the $\mathrm{Cu} / \mathrm{SiC}$ system. Acta Mater, 2000, 48(18-19), 4483-4491.

7. Gasse, A., Chaumat, G., Rado, C. and Eustathopoulous, N., Influence of atmosphere on the wettability of $\alpha-\mathrm{SiC}$ by non-reactive $\mathrm{Cu}-\mathrm{Si}$ alloys. $J$. Mater. Sci. Lett., 1996, 18(15), 1630-1632.

8. Tang, W. M., Zheng, Z. X., Ding, H. F. and Jin, Z. H., A study of the solid state reaction between silicon carbide and iron. Mater. Chem. Phys., 2002, 74(3), 258-264.

9. Schiepers, R. C. J., Van Beek, J. A., van Loo, F. J. J. and de With, G., The interaction between $\mathrm{SiC}$ and $\mathrm{Ni}, \mathrm{Fe}(\mathrm{Fe}, \mathrm{Ni})$ and steel: Morphology and kinetics. J. Eur. Ceram. Soc., 1993, 11, 211-218.

10. Hansen, M. and Anderko, K., Constitution of Binary Alloys, vol. 1. McGrawHill, New York, 1958, pp. 1039-1041.

11. Schiepers, R. C. J., Van Loo, F. J. J. and De With, G., Reactions between $\alpha-$ silicon carbide ceramic and nickel or iron. J. Am. Ceram. Soc., 1988, 71(6), C-284-C-287.

12. Tréheux, D., Lourdin, P., Mbongo, B. and Juve, D., Metal-ceramic solid state bonding: mechanisms and mechanics. Scripta Metall. Mater., 1994, 31(8), 1055-1060.

13. Lourdin, P., Juvé, D. and Tréheux, D., Nickel-alumina bonds: mechanical properties related to interfacial chemistry. J. Eur. Ceram. Soc., 1996, 16(7), $745-752$.

14. Lamy M., Etude structurale et chimique par microscopie électronique en transmission d'interface $\mathrm{SiC} /$ siliciures de $\mathrm{Co}, \mathrm{Fe}$ ou $\mathrm{Ni}$, Thèse Institut national polytechnique de Grenoble, janvier 2000.
15. Stremsdoerfer, G., Procédé direct de revêtement métallique par projection de solution aqueuses sur tout type de substrat, Brevet 97 06-834, publication n ${ }^{\circ}$ FR276396 1997.

16. Stremsdoerfer, G., Ghanem, F., Saikali, Y. and Fares Karim, A., Copper deposition by dynamic chemical plating. J. Mater. Sci., 2003, 38, 3291-13291.

17. Berztiss, R. R., Cerchiara, E. A., Gulbransen pettit, F. S. and Meier, G. H., Oxidation of $\mathrm{MoSi}_{2}$ and comparison with other silicide materials. Mater. Sci. Eng. A, 1992, A155, 165-.

18. Aoki, K. and Izumi, O., Improvement in room temperature ductility of the intermetallic compound $\mathrm{Ni}_{3} \mathrm{Al}$ by ternary trace element addition. Nippon Kinzoku Gakkai Shi J. Jpn. Inst. Met., 1979, 43, 358-359.

19. Aoki, K. and Izumi, O., Improvement in room temperature ductility of the intermetallic compound $\mathrm{Ni}_{3} \mathrm{Al}$ by boron addition. Nippon Kinzoku Gakkai Shi J. Jpn. Inst. Met., 1979, 43, 1190-1196.

20. Kara-Slimane, A., Mbongo, B. and Tréheux, D., Adhesion and reactivity in the copper-alumina system: influence of oxygen and silver. J. Adhesion Sci. Technol., 1999, 13, 35-48.

21. Serier, B. and Tréheux, D., Silver-alumina solid state bonding: study of the work hardening of the metal. Acta Metall. Mater., 1993, 41(2), 369374.

22. Meyer, M. K., Kramer, M. J. and Akinca, M., Boron-doped molybdenum silicides. Adv. Mater, 1996, 8(1), 85-88.

23. Xiong, H., Mao, W., Xie, Y., Guo, W., Li, X. and Cheng, Y., Brazing of SiC to a wrought nickel-based superalloy using $\mathrm{CoFeNi}(\mathrm{Si}, \mathrm{B}) \mathrm{CrTi}$ filler metal. Mater. Lett., 2007.

24. Johnson, S. M. and Rowcliffe, D. J., Mechanical properties of joined silicon nitride. J. Am. Ceram. Soc., 1985, 68(9), 468-472.

25. Bosselet, F., Viala, J.C. \& Bouix, J., Isotherme à $1000^{\circ} \mathrm{C}$ du système ternaire Al-Ni-Si, Compte rendus 19éme JEEP, Barcelone (SP), 30-31 Mars, 1993, 257-62.

26. Tréheux, D., Heurtel, A. and Guiraldeng, P., Etude de l'Héterodiffsuion en volume et aux joints de l'argent dans le nickel. Acta Met., 1976, 24, 503509.

27. Hirone, T., Miura, S. and Susuoka, T., Diffusion of nickel in silver. J. Phys. Soc. Japan, 1961, 16, 2456-2459. 